\title{
Kajian Keselamatan dan Kesehatan Kerja ( K3 ) Konstruksi Balok Pada Konstruksi Bangunan Gedung
}

\section{Occupational Safety and Health (OSH) Study Beam Construction in Building Construction}

\author{
Hendra Alexander, Silvia Nengsih \& Oni Guspari \\ Jurusan Teknik Sipil Politeknik Negeri Padang Kampus Limau Manis Padang \\ Telp. 0751-72590 Fax. 0751-72576 Email: hendra.alexander@ gmail.com
}

\begin{abstract}
Construction projects have a very high risk of work accidents. Work accidents will disrupt all project activities that can cause death and loss to the project. A work accident is an undesirable and unexpected incident which could result in loss of life and property. Based on Law No.1 of 1970 concerning work safety, work accident is an unexpected and undesirable event that disrupts the regulated process of an activity and can cause harm to both human victims and property.

For this reason, it is necessary to have a construction safety management system using methods Hazard Identification Risk Determining Control (HIRADC). HIRADC will be implemented if there is support from management for occupational safety and health $(\mathrm{OSH})$ in the form of policies, organizational structure and budget.

From the studies conducted, the most common hazards are falling, punctured, scratched, tripped, bumped, inhaled dust, electric shock, exposed to concrete splashes with extreme risk of risk of injury, disability and even death. For this reason, there is a need for handling control in the form of mandating the use of PPE, administrative control such as making work instructions, SOP, must have SIO and SILO, installing signs, and doing engineering such as work methods, shopdrawing, providing regular training.
\end{abstract}

Keyword : construction project, work safety, hazard, risk, HIRADC, PPE

\section{PENDAHULUAN}

Pembangunan proyek konstruksi beresiko sangat tinggi yaitu terjadinya kecelakaan kerja. Kecelakaan kerja akan menganggu semua kegiatan proyek yang dapat menyebabkan kematian dan kerugian pada proyek. Setiap proyek konstruksi terutama proyek konstruksi bangunan gedung mempunyai resiko kecelakaan kerja yang tinggi yang dapat menyebabkan kerugian secara finansial dan waktu sampai menyebabkan kematian.

Adapun masalah yang penulis kaji adalah mengidentifikasi bahaya, membuat penilaian resikonya serta merencanakan pengendalian resiko pada pekerjaan balok konstruksi bangunan gedung dengan lokasi
Proyek Pasar Atas Bukittinggi supaya tidak terjadi kecelakaan kerja atau zero accident.

Berdasarkan UU No. 1 Tahun 1970 tentang keselamatan kerja, kecelakaan kerja adalah suatu kejadian yang tidak diduga semula dan tidak dikehendaki, yang mengacaukan proses yang telah diatur dari suatu aktivitas dan dapat menimbulkan kerugian baik korban manusia maupun harta benda. Menurut PP Nomor 50 tahun 2012, Keselamatan dan Kesehatan Kerja (K3) Konstruksi adalah segala kegiatan untuk menjamin dan melindungi keselamatan dan kesehatan tenaga kerja melalui upaya pencegahan kecelakaan kerja dan penyakit pada pekerja konstruksi. Menurut Slamet (2012) yang dikutip Dewi Ratna (2017), keselamatan kerja dapat 
diartikan sebagai keadaan terhindar dari bahaya selama melakukan pekerjaan.

Peraturan Menteri Tenaga Kerja (Permenaker) Nomor : 03/Men/1998, Kecelakaan kerja adalah suatu kejadian yang tidak dikehendaki dan tidak diduga semula yang dapat menimbulkan korban jiwa dan harta benda.

Construction safety plan adalah suatu perencanaan K3 yang disusun untuk meminimalisir terjadinya kecelakaan kerja untuk menuju zero accident pada proyek konstruksi. Construction safety plan ini dimulai dengan mengidentifikasi bahaya yang dapat menyebabkan resiko kecelakaan kerja kemudian membuat penilaian resiko serta dilakukan pengendalian dengan menyusun rencana pengendalian resiko dan diimplementasi di lapangan. (Alexander dkk, 2019).

Menurut Bangun Wilson (2012) Keselamatan Kerja adalah perlindungan atas keamanan kerja yang dialami pekerja baik fisik maupun mental dalam lingkungan pekerjaan.

Adapun klasifikasi kecelakaan kerja berdasarkan tingkat keparahannya yaitu ( Ihsan, 2011 ):

1. Fatal/Meninggal :

Kecelakaan yang menyebabkan kematian tanpa memperhitungkan tenggang waktu antara terjadinya kecelakaan dengan meninggalnya korban.

2. Berat.

Kecelakaan kerja berat yakni kecelakaan kerja yang mengalami amputasi dan kegagalan fungsi tubuh. Seperti patah tulang, cacat, hingga amputasi.

3. Sedang.

Kecelakaan kerja sedang yaitu kecelakaan yang membutuhkan pengobatan dan perlu istiraha selama lebih dari 2 hari. Seperti terjepit, luka sampai robek, luka bakar.

4. Ringan.

Kecelakaan kerja ringan merupakan kecelakan yang membutuhkan pengobatan di hari itu dan dapat melakukan pekerjaannya kembali atau istirahat kurang dari 2 hari. Seperti terpeleset, tergores, terkena pecahan beling, terjatuh dan terkilir.

Resiko adalah kombinasi antara kemungkinan terjadi suatu kejadian/frekuensi dan konsekuensi dari peristiwa tersebut dalam hal ini cidera atau sakit (Ramli, 2011). Sedangkan manjemen resiko merupakan suatu upaya untuk mengatur serta mengelola dan mengendalikan resiko agar dapat mengenali resiko dan mengembangkan strategi untuk meminimalisir resiko (Wideman, 1992).

HIRADC merupakan sebuah sistem untuk menganalisis risiko yang terdiri dari 3 tahapan yaitu identifikasi bahaya (Hazard Identification), penilaian resiko (Risk Assesment) dan pengendalian resiko (Risk Control).

a. Identifikasi Bahaya

Identifikasi bahaya dimaksudkan untuk dapat mengetahui seberapa besar potensi bahaya yang akan terjadi di lingkungan kerja. Hal ini dapat diketahui dengan mengetahui karakter dan sifat bahaya sehingga dapat dilakukan langkah-langkah pengamanan agar tidak terjadi kecelakaan.

b. Penilaian Resiko

Penilaian resiko dapat dilakukan setelah mengidentifikasi semua kemungkinan bahaya. Hal ini dimaksudkan untuk menentukan prioritas pengendalian terhadap tingkat resiko kecelakaan dengan meninjau aspek kuantitatif (kemungkinan) dan aspek kualitatif (dampak). Selanjutnya dari kedua aspek tersebut dimasukkan ke 
dalam matriks reiko untuk menentukan tingkat resiko.

Tabel 1. Kategori Kemungkinan Resiko

\begin{tabular}{|c|c|c|}
\hline Tingkat & Uraian & Conton Rinci \\
\hline 1 & Jarng Teriadi & Dapat teriadi dalam keadaan tertentu \\
\hline 2 & Kadang Terjadi & Dapat terjadi tetapi kemungkinan kecil \\
\hline 3 & DapatTerjadi & Dapat teriadi namun tidak sering \\
\hline 4 & Sering Terjadi & Terjadi beberappa kali dalam beberapa waktu tetentu \\
\hline 5 & Hampir Pasti Terjadi & Dapat terjadi setiap saat dalam kondisi normal \\
\hline
\end{tabular}

Tabel 2. Kategori Konsekuensi

\begin{tabular}{|c|l|l|}
\hline Tingkat & \multicolumn{1}{|c|}{ Uraian } & \multicolumn{1}{c|}{ Contoh Rinci } \\
\hline 1 & Tidak Signifikan & $\begin{array}{l}\text { Kejadian tidak menimbulkan kerugian atau cedera pada } \\
\text { manusia. }\end{array}$ \\
\hline 2 & Kecil & $\begin{array}{l}\text { Menimbulkan cedera ringan, kerugian kecil, dan tidak } \\
\text { menimbulkan dampak serius. }\end{array}$ \\
\hline 3 & Sedang & $\begin{array}{l}\text { Cedera dan dirawat dirumah sakit tidak menimbulkan } \\
\text { cacat tetap, kerugian finansial sedang. }\end{array}$ \\
\hline 4 & Berat & $\begin{array}{l}\text { Menimbulkan cedera parah dan cacat tetap dan kerugian } \\
\text { finansial besar serta menimbulkan dampak serius. }\end{array}$ \\
\hline 5 & Bencana & $\begin{array}{l}\text { Mengakibatkan korban meninggal dan kerugian parah, } \\
\text { bahkan dapat menghentikan kegiatan selamanya }\end{array}$ \\
\hline
\end{tabular}

Tabel 3. Matrik Probalitas dan Dampak

\begin{tabular}{|l|c|c|c|c|c|c|}
\hline \multicolumn{1}{|c|}{ Kemungkinan } & \multicolumn{5}{c|}{ Konsekusensi } \\
\hline & & $\begin{array}{c}\text { Tidak } \\
\text { Signifikan }\end{array}$ & Kecil & Sedang & Berat & Bencana \\
\hline \multicolumn{2}{|c|}{} & 1 & 2 & 3 & 4 & 5 \\
\hline Jarang Terjadi & 1 & 1 & 2 & 3 & 4 & 5 \\
\hline Kadang Terjadi & 2 & 2 & 4 & 6 & 8 & 10 \\
\hline Dapat Terjadi & 3 & 3 & 6 & 9 & 12 & 15 \\
\hline Sering Terjadi & 4 & 4 & 8 & 12 & 16 & 20 \\
\hline Hampir Pasti Terjadi & 5 & 5 & 10 & 15 & 20 & 25 \\
\hline
\end{tabular}

$\geq 10=$ Resiko Ekstrim, pekerjaan harus dihentikan, dan dilakukan investigasi untuk tindakan perbaikan secara menyeluruh oleh manajemen perusahaan

8 - 9 = Resiko Tinggi, dilakukan perbaikan segera dari manajemen perusahaan

$4-6$ = Resiko Sedang, perlu perbaikan dari manajemen di proyek

$2-3=$ Resiko Rendah, perlu perhatian dari manajemen di proyek

$1=$ Tidak Significant

(Sumber: Jurnal Analisis Risiko K3 Menggunakan Pendekatan HIRADC dan JSA, 2017) c. Pengendalian Resiko

Setelah memberikan penilaian terhadap resiko, langkah berikutnya adalah melakukan tindakan pengendalian resiko yang dilakukan terhadap seluruh bahaya yang ditemukan dalam proses identifikasi bahaya dan mempertimbangkan peringkat resiko. Tindakan pengendalian resiko memiliki hirarki sebagai berikut :

\section{$>$ Eliminasi}

Pengendalian ini dilakukan dengan menghilangkan sumber bahaya itu sendiri.

\section{$>$ Substitusi}

Pengendalian ini dilakukan dengan mengganti alat, bahkan serta sistem dengan yang lebih aman .

\section{> Pengendalian Teknik}

Dalam pengendalian teknik, bahaya dan pekerja dipisah untuk mencegah terjadinya kesalahan yang diakibatkan oleh manusia yang terpasang dalam suatu unit sistem mesin atau peralatan.

$>$ Pengendalian Administratif Dapat dilakukan dengan seleksi karyawan, memiliki Standart of Prosedure.

\section{Alat Pelindung Diri (APD)}

Dilakukan penerapan APD kepada pekerja untuk mengurangi risiko dan dampak bahaya namun hal ini merupakan pengendalian yang kurang efektif.

\section{METODOLOGI}

Metodologi dalam penelitian dimulai dari tahapan penelitian yang meliputi survey dan observasi untuk mengumpulkan data di lokasi proyek. Setelah itu dilakukan pengolahan data dengan menggunakan metoda HIRADC, mengidentifikasi bahaya, 
menilai resiko dari bahaya tersebut, serta membuat rencana pengendalian dari resiko tersebut. Adapun tahapan penelitian secara skematis bisa dilihat pada.flowchart

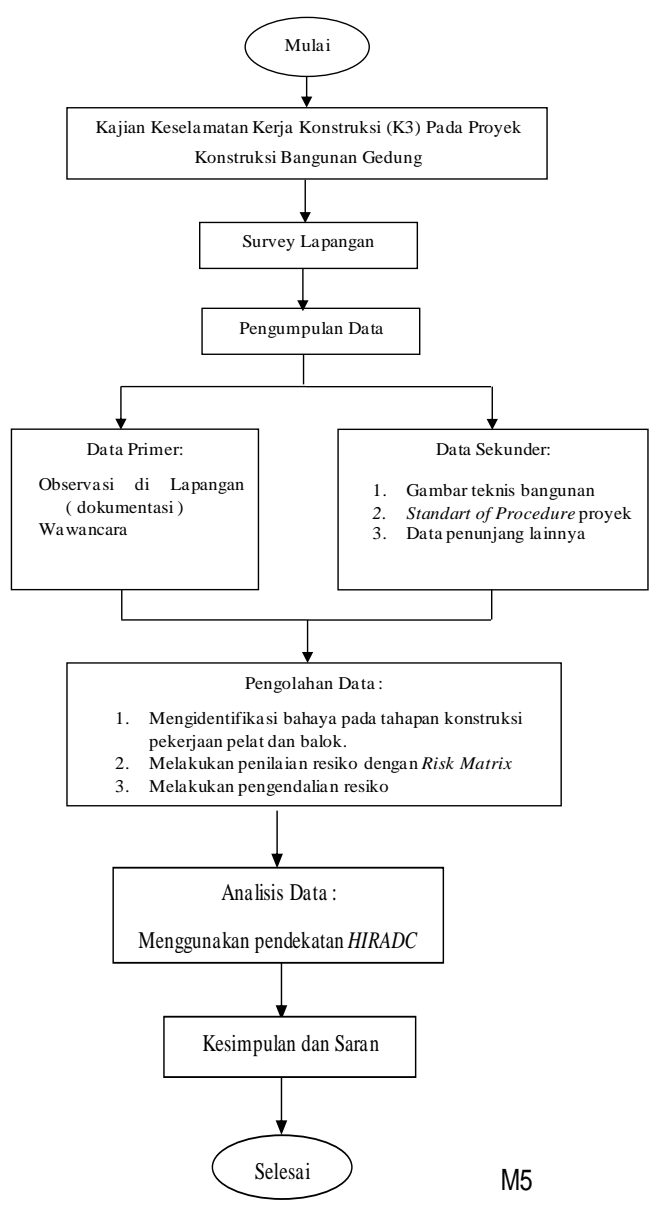

Gambar 1. Bagan Alir Tahapan Proses Penelitian.

\section{HASIL DAN PEMBAHASAN}

Dari data yang didapatkan dibuatkan matrik probilitas dn dampaknya yang berisikan uraian pekerjaan, identifikasi bahaya dari pekerjaan, penilaian resiko dan resikonya, pengendalian resiko.

Uraian kegiatan pada pekerjaan balok adalah

1. Pemasangan perancah oleh pekerja yang tidak berkompeten.

2. Perancah yang tidak lengkap.
3. Pengangkatan frame dan asesoris perancah dengan tower crane.

4. Pembuatan panel bekisting.

5. Pengangkatan panel bekisting

6. Pemasangan atau perakitan panel bekisting.

7. Pemotongan besi dan pembengkokan begel besi.

8. Pengangkatan besi

9. Pemasangan atau perakitan besi

10. Truk mixer memasuki lokasi proyek.

11. Pengecoran dan pemadatan beton

\section{Identifikasi bahaya}

Identifikasi bahaya mutlak harus dilakukan pada metoda HIRADC. Identifikasi bahaya ini merupakan suatu usaha untuk mengetahui bahaya apa saja yang bisa terjadi pada setiap pekerjaan. Dari identifikasi bahaya yang dilakukan, bahaya yang bisa terjadi yaitu : terjatuh, tertimpa, terjepit, terbentur, tergores, terhirup debu, terpukul palu, tersandung, terhimpit, tertusuk, tersengat listrik, perancah rubuh, sling putus, terpotong, terkena percikan beton. 
Tabel 1. Identifikasi Bahaya Pekerjaan Balok

\begin{tabular}{|c|c|c|}
\hline No. & Uraian Pekerjaan & Identifikaasi Bahaya \\
\hline 1 & 2 & 3 \\
\hline \multicolumn{3}{|c|}{ A. Pekerjaan Balok Pada Konstruksi Bangunan Gedung } \\
\hline \multicolumn{3}{|c|}{ Pemasangan Perancah/Scafolding } \\
\hline 1 & $\begin{array}{l}\text { Pemasangan Perancah } \\
\text { oleh pekerja yang tidak } \\
\text { berkompeten }\end{array}$ & $\begin{array}{l}\text { - Terjatuh } \\
\text { - Terjepit } \\
\text { - Terbentur }\end{array}$ \\
\hline 2 & $\begin{array}{l}\text { Perancah yang tidak } \\
\text { lengkap atau non standar }\end{array}$ & $\begin{array}{l}\text { - Perancah rubuh } \\
\text { - Tertimpa } \\
\text { - Terjatuh } \\
\text { - Perancah rusak }\end{array}$ \\
\hline 3 & $\begin{array}{l}\text { Pengangkatan frame dan } \\
\text { asesoris perancah dengan } \\
\text { tower crane }\end{array}$ & $\begin{array}{l}\text { - Sling Putus } \\
\text { - Tertimpa } \\
\text { - Terbentur }\end{array}$ \\
\hline \multicolumn{3}{|c|}{ Pekerjaan Bekisting } \\
\hline 1 & Pembuatan panel bekisting & $\begin{array}{l}\text { - Terpotong } \\
\text { - Terhirup debu } \\
\text { - Tergores } \\
\text { - Terpukul palu } \\
\text { - Tersandung } \\
\text { - Tertusuk } \\
\text { - Terhimpit }\end{array}$ \\
\hline 2 & Pengangkatan panel bekisting & $\begin{array}{l}\text { - Sling Putus } \\
\text { - Tertimpa } \\
\text { - Terbentur }\end{array}$ \\
\hline 3 & $\begin{array}{l}\text { Pemasangan/Perakitan } \\
\text { Panel Bekisting }\end{array}$ & \begin{tabular}{|l} 
- Teriatuh \\
- Terpotong \\
- Terhirup debu \\
- Tergores \\
- Terpukul palu \\
- Tersandung \\
- Tertusuk \\
\end{tabular} \\
\hline
\end{tabular}

\begin{tabular}{|c|c|c|}
\hline No. & Uraian Pekerjaan & Identifikaasi Bahaya \\
\hline 1 & 2 & 3 \\
\hline \multicolumn{3}{|c|}{ Pekerjaan Pembesian } \\
\hline 1 & $\begin{array}{l}\text { Pemotongan dan pabrikasi } \\
\text { begel }\end{array}$ & $\begin{array}{l}\text { - Terpotong } \\
\text { - Tergores } \\
\text { - Tersandung } \\
\text { - Tertusuk } \\
\text { - Terhimpit }\end{array}$ \\
\hline 2 & Pengangkatan besi & $\begin{array}{l}\text { - Sling Putus } \\
\text { - Tertimpa } \\
\text { - Terbentur }\end{array}$ \\
\hline 3 & Pemasangan pembesian & $\begin{array}{l}\text { - Terjatuh } \\
\text { - Tergores } \\
\text { - Tersandung } \\
\text { - Tertusuk }\end{array}$ \\
\hline \multicolumn{3}{|c|}{ Pekerjaan Pengecoran } \\
\hline 1 & $\begin{array}{l}\text { Truck masuk lokasi proyek } \\
\text { menuju pompa }\end{array}$ & - Tertabrak \\
\hline 2 & Pengecoran dan pemadatan & $\begin{array}{l}\text { - Terjatuh } \\
\text { - Tersandung } \\
\text { - Terkena percikan beton } \\
\text { - Tersengat listrik }\end{array}$ \\
\hline
\end{tabular}

\section{Penilaian Resiko}

Tahapan setelah identifikasi bahaya adalah melakukan penilian resiko dari bahaya tadi. Penilaian resiko bertujuan untuk mengetahui tingkat resiko dan resikonya sehingga akan apat membuat pandangan apakah bahaya tesebut bisa dimaklumi atau tidak. Dari penilaian resiko yang dilakukan, hampir semua kegiatan pekerjaan mendapatkan nilai 16 - 20. Ini berarti kegiatan pekerjaan mempunyai tingkat resiko ekstrim yang beresiko kematian dan cacat serta berakibat pekerjaan di proyek bisa dihentikan untuk keperluan investigasi. Apabila proyek sampai dihentikan untuk keperluan investigasi tentu akan dapat mengalami kerugian waktu dan materil. 
Tabel 2. Penilaian Resiko Pekerjaan Balok

\begin{tabular}{|c|c|c|c|c|c|}
\hline \multirow[b]{2}{*}{ No. } & \multirow[b]{2}{*}{ Uraian Pekerjaan } & \multicolumn{4}{|c|}{ Penilaian Resiko } \\
\hline & & Kerapatan & Keparahan & $\begin{array}{l}\text { Tingkat } \\
\text { Resiko }\end{array}$ & Resiko \\
\hline 1 & 2 & 4 & 5 & 6 & 7 \\
\hline \multicolumn{6}{|c|}{ A. Pekerjaan Balok Pada Konstruksi Bangunan Gedung } \\
\hline Pemasa & ingan Perancah/Scafolding & & & & \\
\hline 1 & $\begin{array}{l}\text { Pemasangan Perancah } \\
\text { oleh pekerja yang tidak } \\
\text { berkompeten }\end{array}$ & 4 & 5 & 20 & $\begin{array}{l}\text { Meninggal } \\
\text { Cacat } \\
\text { Cedera }\end{array}$ \\
\hline 2 & $\begin{array}{l}\text { Perancah yang tidak } \\
\text { lengkap atau non standar }\end{array}$ & 4 & 5 & 20 & $\begin{array}{l}\text { Meninggal } \\
\text { Cacat } \\
\text { Cedera }\end{array}$ \\
\hline 3 & $\begin{array}{l}\text { Pengangkatan frame dan } \\
\text { asesoris perancah dengan } \\
\text { tower crane }\end{array}$ & 4 & 5 & 20 & $\begin{array}{l}\text { Meninggal } \\
\text { Cacat } \\
\text { Cedera }\end{array}$ \\
\hline \multicolumn{6}{|c|}{ Pekerjaan Bekisting } \\
\hline 1 & Pembuatan panel bekisting & 4 & 4 & 16 & $\begin{array}{l}\text { Cacat } \\
\text { Cedera }\end{array}$ \\
\hline 2 & Pengangkatan panel bekisting & 4 & 5 & 20 & $\begin{array}{l}\text { Meninggal } \\
\text { Cacat } \\
\text { Cedera }\end{array}$ \\
\hline 3 & $\begin{array}{l}\text { Pemasangan/Perakitan } \\
\text { Panel Bekisting }\end{array}$ & 4 & 5 & 20 & $\begin{array}{l}\text { Meninggal } \\
\text { Cacat } \\
\text { Cedera }\end{array}$ \\
\hline Pekeria & Ian Pembesian & & & & \\
\hline 1 & $\begin{array}{l}\text { Pemotongan dan pabrikasi } \\
\text { begel }\end{array}$ & 4 & 4 & 16 & $\begin{array}{l}\text { Cacat } \\
\text { Cedera }\end{array}$ \\
\hline 2 & Pengangkatan besi & 4 & 5 & 20 & $\begin{array}{l}\text { Meninggal } \\
\text { Cacat } \\
\text { Cedera }\end{array}$ \\
\hline 3 & Pemasangan pembesian & 4 & 5 & 20 & $\begin{array}{l}\text { Meninggal } \\
\text { Cacat } \\
\text { Cedera }\end{array}$ \\
\hline Pekerja & an Pengecoran & & & & \\
\hline 1 & $\begin{array}{l}\text { Truck masuk lokasi proyek } \\
\text { menuju pompa }\end{array}$ & 2 & 3 & 6 & Cedera \\
\hline 2 & Pengecoran dan pemadatan & 4 & 5 & 20 & $\begin{array}{l}\text { Meninggal } \\
\text { Cacat } \\
\text { Cedera }\end{array}$ \\
\hline
\end{tabular}

\section{Pengendalian Resiko}

Setelah dilakukan tahapan penilian resiko, tahapan selanjutnya adalah pengendalian resiko. Pada tahapan semua tindakan pengendalian resiko seperti eliminasi, subtitusi, pengendalian teknis, pengendalian administrasi dan pemakain APD harus dijabarkan. Tindakan pengendalian resiko tadi ada yang tidak bisa dilakukan seperti eliminasi pekerjaan, mensubtitusi atau mengganti pekerjaan tersebut dikarenakan keharusan ada atau terkait biaya yang bertambah sangat signifikan. Setelah membuat rencana pengendalian resiko dan diyakini akan bisa diterapkan di proyek, maka dibuatkan penilaian resiko sisa untuk melihat tingkat resikonya.

Pengendalian resiko yang dilakukan adalah

- Mewajibkan setiap pekerja dan orang yang berada dilingkungan proyek untuk memakai alat pelindung diri (APD)

- Pengendalian administrasi yang ketat dan kontiniu.

- Pengecekan kelayakan perancah dan peralatan

- Engineer dan Inspector yang bersertifikat.

- Membuat rekayasa teknik seperti metoda pelaksanaan, SOP, Instruksi Kerja yang harus dilaksanakan pada setiap pekerjaan. 
Tabel 4.2 Pengendalian Resiko Pekerjaan Balok

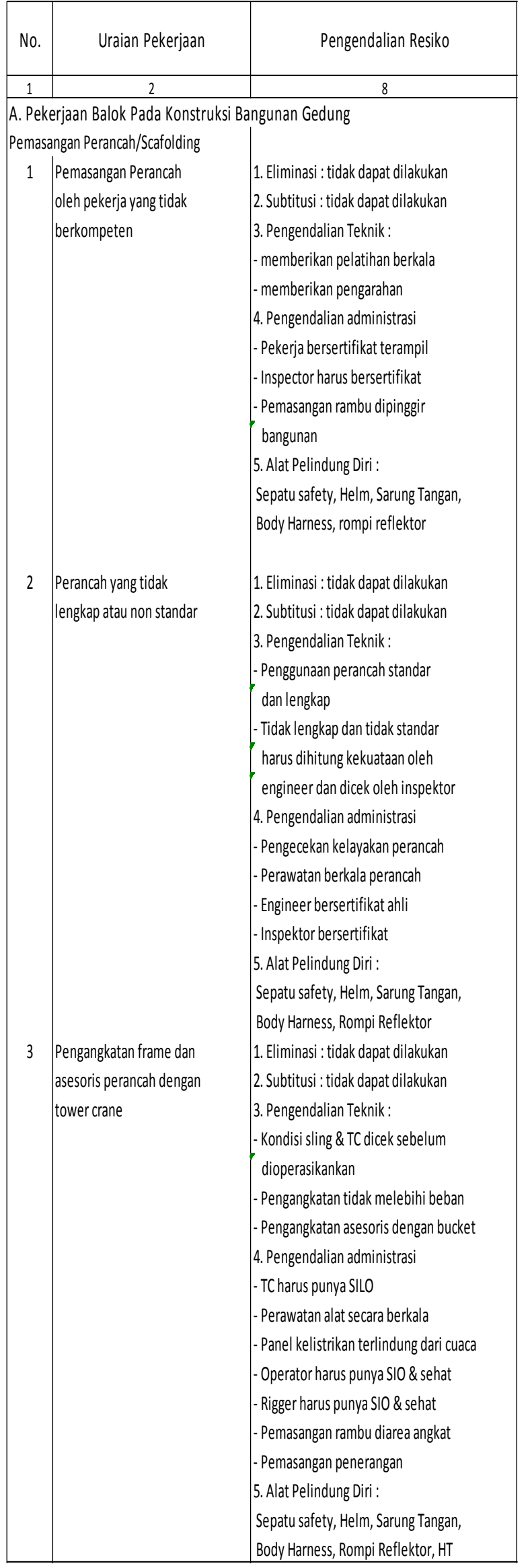

Ianjutan

\begin{tabular}{|c|c|c|}
\hline No. & Uraian Pekerjaan & Pengendalian Resiko \\
\hline 1 & 2 & 8 \\
\hline $\begin{array}{c}\text { Pekerj } \\
1\end{array}$ & $\begin{array}{l}\text { an Bekisting } \\
\text { Pembuatan panel bekisting }\end{array}$ & $\begin{array}{l}\text { 1. Eliminasi : tidak dapat dilakukan } \\
\text { 2. Subtitusi : tidak dapat dilakukan } \\
\text { 3. Pengendalian Teknik: } \\
\text { - Adanya shopdrawing } \\
\text { - Adanya sosialisasi shopdrawing } \\
\text { - Lokasi dibersihkan setiap hari } \\
\text { - Panel bekisting yang mudah dipasang } \\
\text { dan dibongkar } \\
\text { 4. Pengendalian administrasi } \\
\text { - Shopdrawing yang sudah ditanda } \\
\text { tangani oleh semua pihak } \\
\text { - Adanya BA atau notulen sosialisasi } \\
\text { - Pemasangan penerangan } \\
\text { - Pekerja bersertifikat terampil \& sehat } \\
\text { 5. Alat Pelindung Diri : } \\
\text { Sepatu safety, Helm, Sarung Tangan, } \\
\text { Rompi Reflektor, Masker }\end{array}$ \\
\hline 2 & Pengangkatan panel bekisting & $\begin{array}{l}\text { 1. Eliminasi : tidak dapat dilakukan } \\
\text { 2. Subtitusi : tidak dapat dilakukan } \\
\text { 3. Pengendalian Teknik: } \\
\text { - Kondisi sling \& TC dicek sebelum } \\
\text { dioperasikan } \\
\text { - Pengangkatan tidak melebihi beban } \\
\text { 4. Pengendalian administrasi } \\
\text { - TC harus punya SILO } \\
\text { - Perawatan alat secara berkala } \\
\text { - Panel kelistrikan terlindung dari cuaca } \\
\text { - Operator harus punya SIO \& sehat } \\
\text { - Rigger harus punya SIO \& sehat } \\
\text { - Pemasangan rambu diarea angkat } \\
\text { - Pemasangan penerangan } \\
\text { 5. Alat Pelindung Diri : } \\
\text { Sepatu safety, Helm, Sarung Tangan, } \\
\text { Body Harness, Rompi Reflektor, HT }\end{array}$ \\
\hline 3 & $\begin{array}{l}\text { Pemasangan/Perakitan } \\
\text { Panel Bekisting }\end{array}$ & $\begin{array}{l}\text { 1. Eliminasi : tidak dapat dilakukan } \\
\text { 2. Subtitusi : tidak dapat dilakukan } \\
\text { 3. Pengendalian Teknik: } \\
\text { - Adanya shopdrawing } \\
\text { - Adanya sosialisasi shopdrawing } \\
\text { - Tangga dibuat } \\
\text { - Pengecekan kekuatan oleh engineer } \\
\text { dan inspector bersertifikat } \\
\text { 4. Pengendalian administrasi } \\
\text { - Shopdrawing yang sudah ditanda } \\
\text { tangani oleh semua pihak } \\
\text { - Adanya BA atau notulen sosialisasi } \\
\text { - Pemasangan rambu dipinggir } \\
\text { bangunan } \\
\text { - Pemasangan safety deck. } \\
\text { - Pemasangan penerangan } \\
\text { - Pekerja bersertifikat terampil \& sehat } \\
\text { 5. Alat Pelindung Diri : } \\
\text { Sepatu safety, Helm, Sarung Tangan, } \\
\text { Body Harness, Rompi Reflektor, masker }\end{array}$ \\
\hline
\end{tabular}




\begin{tabular}{|c|c|c|}
\hline No. & Uraian Pekerjaan & Pengendalian Resiko \\
\hline 1 & 2 & 8 \\
\hline \multicolumn{3}{|c|}{ Pekerjaan Pembesian } \\
\hline 1 & $\begin{array}{l}\text { Pemotongan dan pabrikasi } \\
\text { begel }\end{array}$ & $\begin{array}{l}\text { 1. Eliminasi : tidak dapat dilakukan } \\
\text { 2. Subtitusi : tidak dapat dilakukan } \\
\text { 3. Pengendalian Teknik: } \\
\text { - Adanya shopdrawing } \\
\text { - Sosialisasi SD ke pekerja } \\
\text { - Lokasi dibersihkan\&tertata setiap hari } \\
\text { 4. Pengendalian administrasi } \\
\text { - Shopdrawing yang sudah ditanda } \\
\text { tangani oleh semua pihak } \\
\text { - Adanya BA atau notulen sosialisasi } \\
\text { - Pemasangan penerangan } \\
\text { - Pekerja bersertifikat terampil \& sehat } \\
\text { - Barcutter\&barbender punya SILO } \\
\text { - Peralatan\&panel listrik terlindung } \\
\text { dari cuaca } \\
\text { 5. Alat Pelindung Diri : } \\
\text { Sepatu safety, Helm, Sarung Tangan, } \\
\text { Rompi Reflektor, Masker }\end{array}$ \\
\hline 2 & Pengangkatan besi & $\begin{array}{l}\text { 1. Eliminasi : tidak dapat dilakukan } \\
\text { 2. Subtitusi : tidak dapat dilakukan } \\
\text { 3. Pengendalian Teknik: } \\
\text { - Kondisi sling \& TC dicek sebelum } \\
\text { dioperasikan } \\
\text { - Pengangkatan tidak melebihi beban } \\
\text { - Pengangkutan begel dengan bucket } \\
\text { 4. Pengendalian administrasi } \\
\text { - TC harus punya SILO } \\
\text { - Perawatan alat secara berkala } \\
\text { - Operator harus punya SIO \& sehat } \\
\text { - Rigger harus punya SIO \& sehat } \\
\text { - Pemasangan rambu diarea angkat } \\
\text { - Pemasangan penerangan } \\
\text { 5. Alat Pelindung Diri : } \\
\text { Sepatu safety, Helm, Sarung Tangan, } \\
\text { Body Harness, Rompi Reflektor, HT }\end{array}$ \\
\hline 3 & Pemasangan pembesian & $\begin{array}{l}\text { 1. Eliminasi : tidak dapat dilakukan } \\
\text { 2. Subtitusi : tidak dapat dilakukan } \\
\text { 3. Pengendalian Teknik: } \\
\text { - Adanya shopdrawing } \\
\text { - Adanya sosialisasi shopdrawing } \\
\text { - Pembuatan tangga untuk akses } \\
\text { 4. Pengendalian administrasi } \\
\text { - Pemasangan rambu dipinggir } \\
\text { bangunan } \\
\text { - Pemasangan safety deck. } \\
\text { - Pemasangan penerangan } \\
\text { - Pekerja bersertifikat terampil \& sehat } \\
\text { 5. Alat Pelindung Diri : } \\
\text { Sepatu safety, Helm, Sarung Tangan, } \\
\text { Body Harness, Rompi Reflektor, masker }\end{array}$ \\
\hline
\end{tabular}

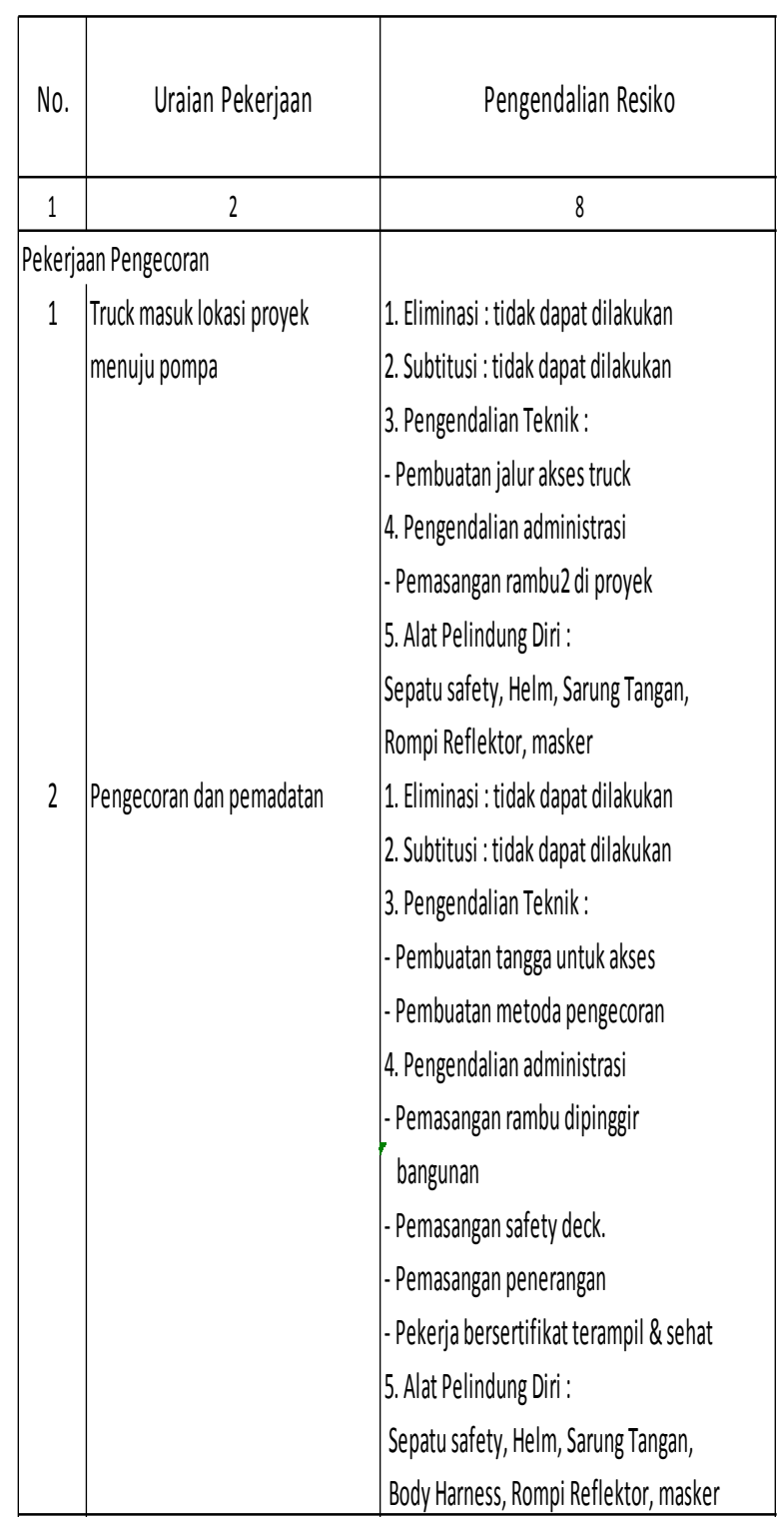

\section{SIMPULAN}

Dari kajian yang dilakukan dapat diambil kesimpulan bahwa :

- Pada pekerjaan balok dan pelat proyek konstruksi bangunan gedung bahaya yang dapat diidentifikasi adalah terjatuh, terjepit, tertusuk, tergores, tertimpa, terhirup debu, tersandung, tersengat listrik. Penilaian resiko berkisar antara 16 - 20 dengan tingkat resiko ekstrim yang beresiko kematian dan cacat. Dan ada penilaian resiko $\leq 6$ dengan tingkat resiko sedang yang beresiko cedera. 
- Setelah dilakukan penilaian resiko dilakukan pengendalian resiko untuk meminimalkan resiko. Pengendalian resiko yang wajib dilaksanakan di proyek adalah menggunakan alat pelindung diri (APD) seperti sepatu safety, helm, sarung tangan, masker, body harness, rompi reflektor. Dilakukan juga pengendalian administrasi seperti operator dan pekerja mempunyai surat ijin operasi (SIO), sertifikat ahli dan terampil. Setiap peralatan yang dipergunakan harus mempunyai surat ijin laik operasi (SILO), memasang rambu peringatan dan bahaya serta penerangan yang cukup. Setelah itu juga dilakukan pengendalian rekasaya seperti membuat metoda yang aman, cepat dan biaya efektif, membuat dan menjalankan SOP, instruksi kerja.

\section{DAFTAR PUSTAKA}

Anonim, 2018. Himpunan Peraturan

Perundang - Undangan Keselamatan dan Kesehatan Kerja

Alexander dkk, 2019. Construction Safety Plan Pada Gedung Bertingkat Berdasarkan Peraturan Menteri Pekerjaan Umum Nomor 05/PRT/M/2014, Jurnal Ilmiah Rekayasa Sipil Vol 16. Nomor 1

Alfatiyah, R. 2017. Analisis manajemen risiko keselamatan dan kesehatan kerja dengan menggunakan metode HIRARC pada pekerjaan seksi casting. Jurnal Mesin Teknologi (SINTEK Jurnal). Vol.11 No.2: 88101.
Anestisia, Y., V. Happy P., S. Aditama. 2015. Analisis risiko Keselamatan dan Kesehatan Kerja (K3) dengan metode HIRADC pada proyek konstruksi gedung. Proyeksi Teknik Sipil. Vol.1 No.2 : 157-165.

Jannah, M.R., S.E. Unas., M.H. Hasyim. 2017. Analisis risiko Keselamatan dan Kesehatan Kerja (K3) melalui pendekatan HIRADC dan metode job safety analysis pada studi kasus proyek pembangunan menara $\mathrm{x}$ di jakarta. Jurnal Mahasiswa Jurusan Teknik Sipil. Vol.1 No.2: 1-8.

Sucita, I.K., A.B. Broto. 2011. Indentifikasi dan penanganan risiko $\mathrm{K} 3$ pada proyek konstruksi gedung. Poli Teknologi. Vol.10 No.1: 83-92.

Zulfa, I.M., M.H. Hasyim., S.E. Unas. 2017. Analisis risiko K3 menggunakan pendekatan HIDADC dan JSA. Jurnal Mahasiswa Jurusan Teknik Sipil. Vol.1 No.2: 1-12. 